This work is licensed under a Creative Commons Attribution 4.0 International License.

Ovaj rad dostupan je za upotrebu pod međunarodnom licencom Creative Commons Attribution 4.0.

https://doi.org/10.31820/f.32.2.9

Krzysztof Tomasz Witczak

\title{
GREEK DURATIVE VERBS WITH THE NASAL INFIX AND SUFFIX
}

Krzysztof Tomasz Witczak, PhD, University of Lodz, Poland, krzysztof.witczak@uni.lodz.pl, Łódź

izvorni znanstveni članak

UDK 811.14'02'367.625

rukopis primljen: 9. rujna 2020; prihvaćen za tisak: 25. studenog 2020.

The Indo-European nasal infix presents have so far not been explained from the semantic point of view. The author of this paper argues that the infix ${ }^{*}$-n(e)- originally expressed the feature of durativity. Due to the diachronic externalization of inflection, this nasal morpheme later evolved into a suffix added to the verbal root. Numerous durative verbs with the nasal marker-anare attested as early as the $2^{\text {nd }}$ millennium BCE in the Anatolian languages; cf. Hittite iy-ann-a/i- 'to march, go a long distance', Palaic iyannnai 'he marches (a long distance)' vs. Hitt. i- 'to go', Luw. i-, Hier.Luw. i-, Lat. eō, ìre, Lith. eĩti, OChSl. iti 'id.' (<PIE. ' $\mathrm{h}_{1}$ ei- 'to go'). The durative verbs in question, as well as the related nouns with the durative suffix ${ }^{*}$-ano-, also appear in other Indo-European languages, cf. Toch. B yanem 'they walk, go (for a long time)'.

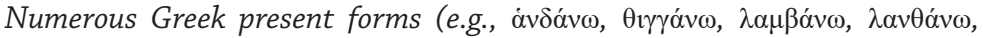
$\lambda \mu \pi \alpha \dot{v} \omega, \mu \alpha v \theta \alpha \dot{v} \omega, \pi v v \theta \alpha \dot{v o} \mu \alpha 1$ and so on) document the same nasal morpheme not only infixed into the verbal root, but also in the form of the suffix -av-. This is to be explained as the effect of the diachronic externalization of the durative (nasal) morpheme. Greek verbal forms with the nasal infix and the nasal suffix should be treated as intermediate forms or hybrids. Newer forms (indicating the durativity of the action) in Greek contain only a nasal suffix

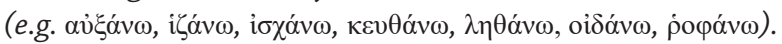

Key words: Ancient Greek; durative verbs; externalization of inflection; Indo-European languages; nasal infix 


\section{Introduction}

There are two competing forms of the verbal roots in the IndoEuropean languages. One is in the full grade, e.g. Gk. $\lambda \varepsilon^{i} i \omega<$ IE. * ${ }^{*} l e i k^{u}-\bar{o}$ $<$ PIE. *leik $k^{u}-e h_{3}(i)$ 'I leave'. The other has the root in the zero grade (i.e. PIE. $\left.{ }^{*} l i k^{u}-\right)$ combined with the nasal infix ${ }^{*}-n(e)-$, e.g. Ved. rinákti, Av. irinaxti 's/he leaves' < PIE. *li-né- $k^{u}-t i 3^{\text {rd }}$ pers. sg. pres. ind.; Lat. linquunt 'they leave' < PIE. *li-n- $k^{u}$-onti $3^{\text {rd }}$ pers. pl. pres. ind., cf. the Greek verb $\lambda \mu \mu$ óvovor 'id.' with the additional nasal suffix (Danka \& Witczak 1990: 317). We note that the semantic difference between the verbal roots with and without the nasal infix has not been hitherto explained. ${ }^{1}$ In his excellent survey of the relevant scholarship Manuel García Teijeiro (1970: 146) states that the exact original function ("significación fundamental") of the $n$-infix at the Indo-European level is unclear and irrecoverable, though the formal identity of the attested $n$-infixed verbal forms appears to be obvious. And more recent research typically arrives at much the same position (cf. Milizia 2003; Bertocci 2014: 482-483; Scheungraber 2014: 18-27). The present author seeks to explicate the matter by showing the durative character of Indo-European verbs containing the nasal morpheme (infix or suffix or both).

\section{Durative verbs with the nasal suffix in the Anatolian languages}

In Hittite and its Anatolian relatives (such as Luwian, Palaic and Lydian) there are numerous verba durativa formed by adding the durative suffix -an- to the basic verbal root, e.g. Hitt. hattanna- 'to cut through, pierce, cut into pieces' (< Hitt. hatta- 'to pierce, cut, wound'), huittiyanna'to pull' (< huittiya- 'to tear, pull'), išhuwanna- 'to pour in, throw' (< išhuwa'to pour, throw'), lahhiyanna- 'to conduct a war campaign' (< lahhiya- 'to set out for war'), nanna- 'to rush' (< nai- 'to lead, send'), paršiyanna- 'to break, tear into pieces' (< paršiya-'id.'), šipandanna- 'to make a liquid offering' (< išpant- 'id.'), tuȟšanna- 'to cut off, separate' (< tuȟša- 'to cut, divide'), walhanna- 'to beat (a slave); play (a musical instrument)' (< walha- 'to hit');' Luwian uppanna- 'to fetch, bring' (< Luw. uppa-), Luw. mammanna- 'to inspect,

1 Standard references on this subject include Strunk 1967; García Teijeiro 1970; Meiser 1993: 280-313; Milizia 2003; 2004: 337-359; Gorbachov 2007; Bertocci 2014: 481-484.

2 The Hittite examples are quoted from the following: Friedrich 1952: 82; Kronasser 1956: 198; Jasanoff 2003: 122; Kloekhorst 2008: 175-176. 
view, evaluate' (< Luw. mana- 'to see'); Lydian sawên- 'to watch, experience' (< Anat. *saw- 'to look'), Lyd. wc-baqên- 'to tread on sth, trample (?)' (< Lyd. baq- and Hitt. pakk- 'to squeeze, destroy'). ${ }^{3}$

The most spectacular durative verbal forms are Hittitte iyanna- 'to march, walk a long distance' and Palaic i-ya-an-na-a-i ( $3^{\text {rd }}$ pers. sg. pres. act.) 's/he marches (a long distance)', which derive from the root Hitt. $i-$, Luw. $i-$, Hier. Luw. $i$ - 'to go'; cf. Lat. ēo, ire 'to go', Lith. eĩti, OChSl. iti 'to go' (Friedrich 1958: 82; Rikov 1997: 9-10; 2001: 191; Kloekhorst 2008: 375)

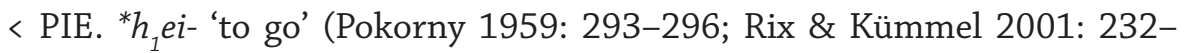
233).

\section{Verbs with the nasal suffix in the other Indo-European languages}

The same durative suffix is found in other Indo-European languages, such as Tocharian; e.g. Toch. B yanem 'they walk, go (for a long time)' is the exact cognate of Hitt. iyannai 's/he marches, walks a long distance' and Pal. $i-y a-a n-n a-a-i$ ( $3^{\text {rd }}$ sg. pres. act.) 's/he marches (a long distance)' (Rikov 1997: 14-17; Jasanoff 2003: 122).

The verbal formations with the nasal suffix are fairly well attested in Armenian, e.g. Arm. $l k^{\text {'anem }}$ 'I leave behind': elik' $3^{\text {rd }}$ pers. sg. aor. 's/he left' (cf. Gk. $\lambda \iota \mu \pi \alpha ́ v \omega$ 'I leave’: '̌̉ $\lambda \iota \varepsilon 3^{\text {rd }}$ pers. sg. aor. act. 's/he left', Ved. áricat (id.'). Other Armenian examples are anicanem 'I chase', gtanem 'I find, discover', dizanem 'I create, form'; usanim 'I learn'; lucanem 'I solve'; Arm. lucanim 'I am freed' (< PIE. *iu-ne-g-, *iu-n-g-, cf. Ved. yunákti, $3^{\text {rd }}$ pers. pl. yuñjánti; Lat. iungō, $3^{\text {rd }}$ pers. pl. iungunt). ${ }^{4}$

\section{Hybrid forms of durative verbs in Ancient Greek}

Greek verba durativa can be formed both from a verbal root with an infix (type A) and from a root without one (type B). The first type (A) is firmly attested in Ancient Greek, e.g.:

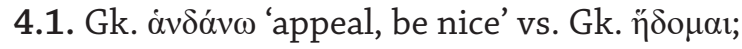

\footnotetext{
3 An extensive review of the Anatolian lexical material with the suffix -anna-can be found in Oettinger (1992: 133-154) and Melchert (1998: 413-418).

4 Further Armenian instances are to be found in the other publications (Klingenschmidt 1982: 124; Rikov 1992: 94; Kočarov 2008: 254-258).
} 


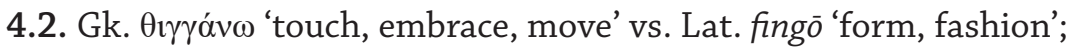

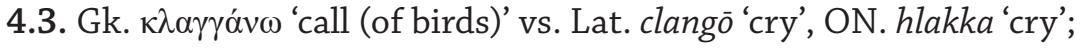

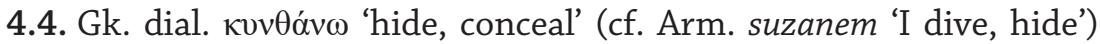
vs. $\kappa \varepsilon v \dot{\theta} \omega$ 'hide, cover, conceal';

4.5. Gk. $\lambda \alpha \mu \beta \alpha ́ v \omega$ 'keep, have (for a long time, forever)' (aor. غ̌ $\lambda \alpha \beta o v$ );

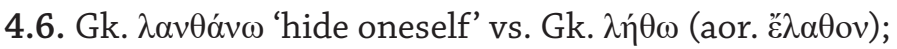

4.7. Gk. $\lambda \iota \mu \pi \alpha ́ v \omega$ 'leave, forsake’ (aor. č $\lambda ı \pi o v)$ vs. Lat. linquō 'leave', Ved. riñcánti $3^{\text {rd }}$ pers. pl. pres. ind. 'they evacute, leave, resign', OPruss. po-linka 's/he stays';

4.8. Gk. $\mu \alpha v \theta \alpha ́ v \omega$ 'learn, get to know, experience' (aor. है $\mu \alpha \theta 0 v)$;

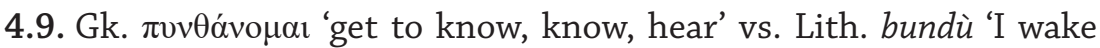

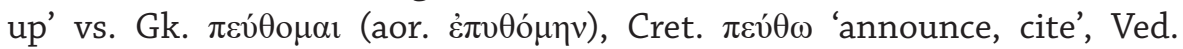
bhódati 's/he watches, perceives, understands', Av. baodaiti 'id.; s/he smells';

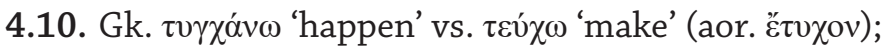

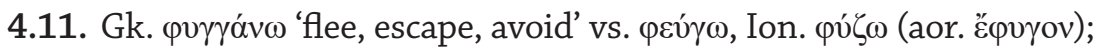

4.12. Gk. $\chi \alpha v \delta \alpha ́ v \omega$ 'include, take up, house' vs. Lat. prae-hendō 'grasp, seize', Alb. gjëndem 'I am found'.

Ancient Greek has a considerable number of durative verbs that have both a nasal infix and a nasal suffix (Brugmann \& Thumb 1913: 335-337; Schwyzer 1939: 699-700; Rix 1976: 211; Willi 2018: 18), whereas Latin and other cognate languages demonstrate only verbs with the nasal infix (see $4.2 ; 4.3 ; 4.7 ; 4.9 ; 4.12$ ). This phenomenon is not attested in any other Indo-European language and requires a separate explanation (cf. sect. 6).

Also type B of the durative verbs is securely attested in Ancient Greek, but it is less frequent and less productive than type A (Rix 1976: 211).

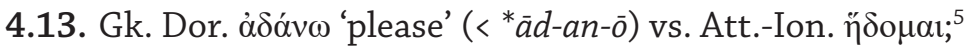

4.14. Gk. $\alpha v \dot{\xi} \dot{\alpha} v \omega$ 'enlarge, multiply vs. $\alpha \dot{\varepsilon} \xi \omega, \alpha \jmath ̉ \xi \omega$;

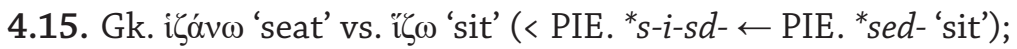

4.16. Gk. i $\sigma \chi \alpha ́ v \omega$ 'keep, hold back, have (permanently)' vs. '̌ $\sigma \chi \omega$ 'keep, hold fast, wield' (< PIE. ${ }^{*} s-i-s \hat{g}^{h_{-}} \leftarrow$ PIE. ${ }^{*} s e \hat{g}^{h_{-}}$'hold, have', cf. Gk. Ě $\chi \omega$ 'possess, retain, have');

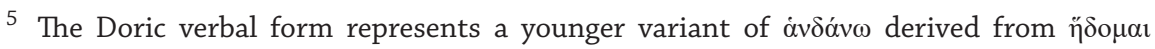
(Beekes 2010: 100). 


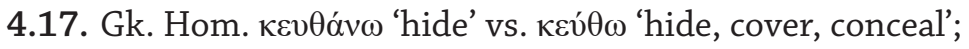

4.18. Gk. $\lambda \eta \theta \dot{\alpha} v \omega$ 'hide oneself' vs. $\lambda \dot{\theta} \theta \omega$ (aor. č $\lambda \alpha \theta o v) ;{ }^{6}$

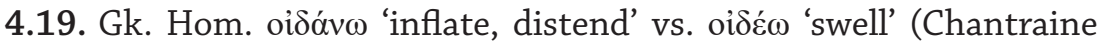
1958: 315);

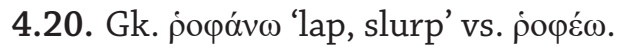

It can thus be readily concluded that the Ancient Greek language replaced the $n$-infixed verbal forms of Indo-European origin (cf. Lat. clango fingō, linquō and so on) by a number of productive items containing both

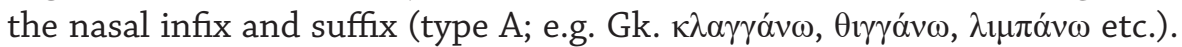
The infix is completely lost in type $B$ (see 4.13-20), which represents a late innovation (cf. 4.13; 4.17; 4.18), also attested in Anatolian, Armenian and Tocharian.

\section{Nominal formations in -avo- with durative meaning.}

The nominal suffix -avo-, which creates numerous Greek nouns and

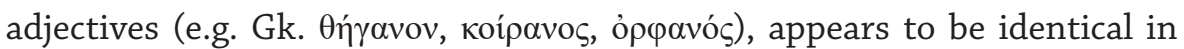
origin with the verbal suffix - $\alpha v$ - (Brugmann \& Thumb 1913: 335), cf. Gk.

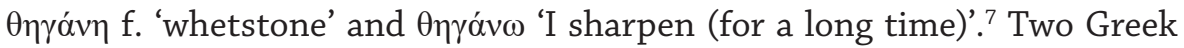
agent nouns in -avos demonstrate exact equivalents in some related languages (including Armenian and Old Phrygian), ${ }^{8}$ as well as in North Indo-European ones (Witczak 2018: 28-29):

5.1. Gk. ỏppavós m. 'an orphan', adj. 'orphan, fatherless, without parents', Arm. arbaneak 'footman, servant, groom' (-eak is a diminutive suffix)

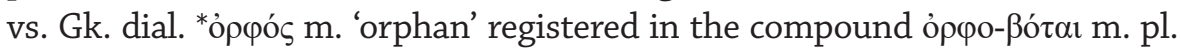
'protectors of the orphans' (< PIE. * $h_{3}$ orb $^{h}$ ós); Arm. orb (o-stem) 'orphan'; Ved. árbha- adj. 'little, small, unimportant', arbhá- m. 'child, boy'; Lat. orbus adj. 'bereaved, bereft; destitute; orphaned, fatherless; childless; widowed', m. 'orphan'; OIr. orb m. (o-stem) 'heir, inheritor'; OChSl. rabs 'servant', Czech rob

6 It is worth emphasizing that this Greek verb $\lambda \eta \theta \alpha \dot{v} \omega$ seems to represent a contamination of both $\lambda \dot{\eta} \theta \omega$ and $\lambda \alpha v \theta \alpha \dot{v} \omega$ 'hide oneself' (see 4.6).

7 According to Brugmann \& Thumb (1913: 335), “Dieser Suffix [= the verbal suffix -óv war wohl identisch mit dem Nominalsuffix -avo-".

8 Both Phrygian and Armenian, spoken in Asia Minor and Caucasus, originally belonged to the Palaeo-Balkan subgroup of the Indo-European languages. In my opinion, Greek, Phrygian and Armenian represent descendant languages which derive from the so-called "Balkan-Indogermanisch" (Witczak 2008: 17-28). 
'slave' (< Slavic *orbs m. 'servant, slave'). The noun * $h_{3}$ orb ${ }^{h}$ ós and the adjective ${ }^{*} h_{3}$ orb $^{\text {h}}$ os are securely motivated by the Hittite verb harp- 'to separate oneself'

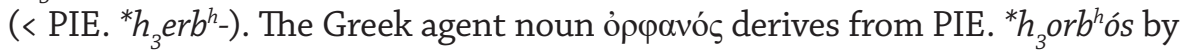
means of the durative suffix -avo-. It must originally have meant 'a person who is separated from his family for a long time'.

5.2. Gk. кoípavos m. 'ruler, leader, commander (in war or peace)', generally 'lord, master', also 'king' in the Boeotian dialect; OPhryg. kuryaneyos adj. 'belonging to the army; leader' (or 'chief, king', according to Lubotsky 1988: 23); ON. Herjann 'Heervater' (Odin's by-name); Lusitanian feminine PN Coriana vs. Lith. karỹs m. (io-stem; $4^{\text {th }}$ accentual paradigm) 'warrior, soldier' (< PIE. *koriós m. 'warrior' $\leftarrow$ PIE. * ker-). It is necessary to reconstruct an agent noun *korianos m. 'warrior fighting for a long time' (hence 'commander, ruler of the army'), derived from the noun *koriós m. 'warrior' by means of the durative suffix -ano-. Obviously, a commander of the army ( ${ }^{*}$ korianos) should be a warrior with a lengthy military experience and not just a simple warrior (PIE. *koriós).

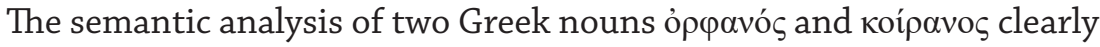
demonstrates that the Greek nominal suffix - $\alpha$ vo- reflects the same durative aspect, which can be observed in Ancient Greek verbs in -óv $\omega$. Close or exact cognates, attested in Armenian, Old Phrygian, Old Norse and Lusitanian, seem to suggest the Indo-European origin of the two Greek agent nouns in question (Witczak 2018: 29). It is worth emphasizing that the durative aspect of the discussed nouns was created (or introduced) by analogy to the durative verbs as early as the Late Indo-European period.

\section{The externalization of the nasal infix in Greek}

At this point I would like to propose a hypothesis that offers an explanation of infixation with the morpheme ${ }^{*}-n$ - and, at the same time, the origin of the Indo-European durative verbs having a nasal suffix. ${ }^{9}$

In my opinion, the Greek verb $\lambda$ cí $\pi \omega$ has the general meaning 'I leave, forsake' (< PIE. *leik $k^{u}$ ) and does not carry any further semantic value. The Latin form linquō is completely different in this respect: Its root is in the zero grade and it exhibits the nasal infix ${ }^{*}-n(e)$-, which I would argue introduces the feature of durativity. In other words, the infixed verbal root

\footnotetext{
9 The hypothesis that the nasal infix was originally a suffix (cf. Kuryłowicz 1964: 106) is not supported by lexical data.
} 
${ }^{*} l i-n(e ́)-k^{u}-$ differed from the basic root ${ }^{*} l e i k^{u}-$ precisely in having the morpheme ${ }^{*}-n-$, which marked the duration of the action. Thus, originally the Proto-Indo-European verbal form * $l i-n-k^{u}-e h_{3}(i)$ had a typically durative meaning: 'to leave, forsake (for a long time, forever)'. By analogy, I treat not only Lat. pingō 'I paint [for a long time]' (hence perf. pīnxī 'I have painted [for a long time]') as a durative verb, but also the Sanskrit form pinkte 'paints [for a long time]' and Toch. B pinkäm 'paints, writes [for a long time]' (< PIE. *pi-n-k-< *peik- 'to write, paint'). The Latin example discussed above shows clearly that the infixation was possible not only in the present stem, but also in the preterite. Other verbs usually lose the nasal infix in the past tense.

As was stressed earlier in the paper, infixation had become a rare phenomenon in the historical Indo-European languages. Furthermore, it became completely unproductive in stark contrast to prefixation or suffixation. This leads us to the assumption that all the verbal roots with the nasal infix are archaic and stem from Proto-Indo-European. Their durative meaning might well have been lost in the course of the long development of the individual Indo-European languages. The externalization of inflection was responsible for the relocation of the nasal morpheme which then became a suffix.

It is likely that the externalization of the nasal morpheme ${ }^{*}-n$ - had two additional stages. ${ }^{10}$ Three models of the creation of durative verbs are attested in the Indo-European languages:

Table 1. Three models of creating durative verbs

\begin{tabular}{|c|c|c|c|}
\hline $\begin{array}{c}\text { Basic } \\
\text { verbal root }\end{array}$ & $\begin{array}{l}\text { (1) Older } \\
\text { model }\end{array}$ & $\begin{array}{l}\text { (2) Transitional } \\
\text { (or hybrid) model }\end{array}$ & $\begin{array}{l}\text { (3) Newer } \\
\text { model }\end{array}$ \\
\hline $\begin{array}{l}\text { PIE. *leik } k^{u}-\text { 'to leave, } \\
\text { forsake' (Rix \& Kümmel } \\
\text { 2001: 406-408) }\end{array}$ & $\begin{array}{l}\text { PIE. }{ }^{*} l i-n-k^{u}- \\
\left({ }^{*} l i-n e ́-k^{u}-\text { in sg. }\right. \\
\text { forms })\end{array}$ & $\begin{array}{l}\text { Late IE. }{ }^{*} l i-n-k^{u}-n_{0}- \\
\text { (a hybrid durative } \\
\text { verb) }\end{array}$ & $\begin{array}{l}\text { Late IE. }{ }^{*}{ }^{*} k^{u}-n_{0}- \\
\text { (a new durative } \\
\text { verb) }\end{array}$ \\
\hline $\begin{array}{l}\text { Gk. } \lambda \text { cí } \omega \omega \text { 'I leave', } \\
\text { Goth. leihan 'to lend', } \\
\text { Lith. lieku 'I leave, put' }\end{array}$ & $\begin{array}{l}\text { Lat. linquō, Ved. } \\
\text { rinákti (pl. } \\
\text { riñcánti), Av. } \\
\text { irinaxti }\end{array}$ & Gk. $\lambda \iota \mu \pi \alpha ́ v \omega$ & Arm. lk'anem \\
\hline
\end{tabular}

Source: Own work.

10 The problem of externalization of inflection in the Indo-European languages is presented in detail by Witczak (2017: 93-111). 
In the older model of inflection (type 1) the verbal root in the zero grade with the nasal infix is the variant of the root in the present tense (PIE. *leik $k^{u}-$ vs. PIE. *li-né- $k^{u}-{ }^{*}{ }^{*} l i-n-k^{u}-$ ). The original character of nasal infixation has not been precisely explained to date. In the newer model (type 3) the nasal morpheme appears as a suffix to the verbal root (in the reduced grade) and the resultant verbal forms have the meaning of an action with a long-time span: 'to leave for a long time, forsake forever'. In other words, the nasal morpheme (with the durative meaning) was relocated from the inside of the root to the outside, precisely to the position at the end of the root.

What seems to be an uncontestable proof of the correctness of the analysis given above is the transitional hybrid model (type 2), in which the nasal morpheme ${ }^{*}-n$ - with durative meaning appears twice, as an infix within the verbal root and as a suffix after the root. In Greek we can find numerous durative verbs with the doubled ${ }^{*}-n-$, e.g. Gk. $\lambda \alpha \mu \beta \alpha \alpha^{\prime} \omega, \lambda \mu \mu \alpha \dot{v} v \omega$, $\mu \alpha v \theta \alpha \dot{v} \omega, \pi v v \theta \alpha ́ v o \mu \alpha 1, \tau v \gamma \chi \alpha ́ v \omega$, which evidently represent innovative formations (Milizia 2003: 182). These Hellenic forms can surely be called "hybrids"11.

All the provided derivational variants are well attested in the IndoEuropean languages and there is no doubt that type (1) represents the older model, type (2) the transitonal (hybrid) model, and type (3) the newer model. In the older model the nasal affix ${ }^{*}-n$ - with a durative meaning is infixed into the verbal root and is always mid-word. In the newer model, the nasal morpheme is added as a suffix to the verbal root, and thus it is placed externally in relation to the root. The change from type (1) to type (3) should be called the externalization of the durative morpheme. This process clearly proves that the verbal roots without the nasal infix are to be considered as basic and unmarked, while the forms with the infix are marked, durative variants.

\footnotetext{
11 Willi (2018: 18) explains the hybrid forms differently. He says: "Because synchronically suffixed nasal presents predominated over infixed ones, a mixed type was created on this

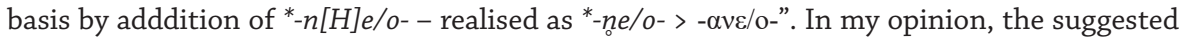
hypothesis of the nasal-infix externalization constitutes a more convincing explanation of the origin of the productive Greek verbs with the nasal infix and suffix.
} 


\section{Conclusions}

The analysis conducted in the present paper leads to the following conclusions:

7.1. In the Indo-European languages we can observe the process of externalization of the nasal morpheme, which was initially an infix inserted into the verbal root, and eventually became a suffix, added to the root.

7.2. Indo-European verbs with the nasal suffix have a durative meaning, which on the basis of the proposed process of the externalization of the nasal morpheme allows us to posit the same meaning for the archaic verbs with the nasal infix.

7.3. The externalization of the nasal infix was a productive process in the Indo-European languages. It is attested not only in Ancient Greek, but also in Armenian, Anatolian, Tocharian, Italic and many other languages of the Indo-European family.

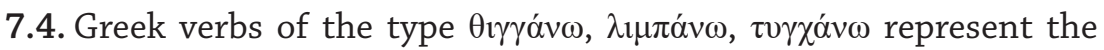
transitional (hybrid) stage of the development. There is no doubt that these forms denote actions with a long-time span.

\section{Acknowledgements}

I would like to express my sincere gratitude to Paul Sheldon Cohen and Mikołaj Rychło for improving my English text, to Elwira Kaczyńska for her help and encouragement, to Ignacy Ryszard Danka, Jerzy Gaszewski and Marek Majer for their comments on my earlier draft, as well as two peer reviewers for valuable remarks and additional references. As regards the final conclusion, I remain solely responsible.

\section{List of abbreviations}

Alb. $=$ Albanian; Anat. $=$ Anatolian; Arm. $=$ Armenian; Av. $=$ Avestan; Cret. $=$ Cretan dialect of Ancient Greek; Gk. = (Ancient) Greek; Goth. = Gothic; Hier. Luw. $=$ Hieroglyphic Luwian; Hom. $=$ Homeric; IE. $=$ Indo-European; Ion. = Ionic dialect of Ancient Greek; Lat. = Latin; Lith. = Lithuanian; Luw. = Luwian; Lyd. = Lydian; OChSl. = Old Church Slavic; OIr. = Old Irish; ON. = Old Norse; OPhryg. = Old Phrygian; OPruss. = Old Prussian; Pal. = Palaic; PIE. = Proto-Indo-European; Toch. $\mathrm{A}=$ Tocharian A or East Tocharian; Ved. $=$ Vedic. 


\section{List of glosses}

act. $=$ active; aor. $=$ aorist; ind. $=$ indicative; pers. = person; pl. = plural; pres. $=$ present; sg. $=$ singular.

\section{References}

Beekes, Robert (2010) Etymological Dictionary of Greek, vol. 1-2, LeidenBoston: Brill.

Bertocci, Davide (2014) Nasal presents, in Giannakis, Georgios K. (ed.) Encyclopedia of Ancient Greek Language and Linguistics, vol. 2, LeidenBoston: Brill, 481-484.

Brugmann, Karl and Thumb, Albert (1913) Griechische Grammatik. Lautlehre, Stammbildungs- und Flexionslehre, Syntax, vierte vermehrte Auflage, München: C. H. Beck'sche Verlagsbuchhandlung, Oskar Beck.

Chantraine, Pierre (1958) Grammaire homérique, vol. 1, Paris: Librairie C. Klincksieck.

Danka, Ignacy Ryszard and Witczak, Krzysztof Tomasz (1990) Some Problems of Indo-European Lexicography, in Tomaszczyk, Jerzy and Barbara Lewandowska-Tomaszczyk (eds.) Meaning and Lexicography, Amsterdam-Philadelphia: John Benjamins Publishing Company.

Friedrich, Johannes (1952) Kratkaja grammatika khettskogo jazyka, Moskva: Izdatel'stvo Inostrannoj literatury.

García Teijeiro, Manuel (1970) Los presentes indoeuropeos con infijo nasal y su evolucion, Salamanca: Consejo Superior de Investigaciones Científicas.

Gorbachov, Yaroslav V. (2007) Indo-European Origins of the Nasal Inchoative Class in Germanic, Baltic and Slavic, unpublished Ph.D. dissertation, Cambridge (MA): Harvard University.

Ivanov, Vjačeslav V. (2001) Khettskij jazyk, Moskva: URSS.

Jasanoff, Jay H. (2003) Hittite and the Indo-European Verb, Oxford: Oxford University Press.

Klingenschmidt, Gert (1982) Das armenische Verbum, Wiesbaden: Dr L. Reichert Verlag.

Kloekhorst, Alwin (2008) Etymological Dictionary of the Hittite Inherited Lexicon, Leiden-Boston: Brill. 
Kočarov, Petr A. (2008) "K voprosu o proiskhoždenii glagol'nogo suffiksa -ana-v drevnearmjanskom", Indoevropejskoe jazykoznanije i klassičeskaja filologia 12: 254-258.

Kronasser, Heinz (1956) Vergleichende Laut- und Formenlehre des Hethitischen, Heidelberg: Carl Winter.

Kuryłowicz, Jerzy (1964) The Inflectional Categories in Indo-European, Heidelberg: Winter.

Lubotsky, Alexander M. (1988) “The Old Phrygian Areyastis Inscription”, Kadmos 27(1): 9-26.

Meiser, Gerhard (1993) Zur Funktion des Nasalpräsens im Urindogermanischen, in: Meiser, Gerhard (ed.) Indogermanica et Italica. Festschrift für Helmut Rix zum 65. Geburtstag, Innsbruck: Institut für Sprachwissenschaft der Universität Innsbruck, 280-313.

Melchert, H. Craig (1998) "Aspects of Verbal Aspect in Hittite", in: Alp, Sedal and Aygül Süel (eds.) Acts of the IIIrd International Congress of Hittitology, Çorum, September 16-22, 1996, Ankara: Uyum Ajans, 413-418.

Milizia, Paolo (2003) Morfofonologia dell'infisso nasale indoeuropeo. Genesi e tipologia dell'infissazione; sopravvivenze in latino, in indoiranico, in ittito, in greco e in baltico, Unpublished Ph.D. dissertation, Milano: Università degli Studi di Milano.

Milizia, Paolo (2004) "Proto-Indo-European nasal infixation rule", The Journal of Indo-European Studies 32: 337-359.

Oettinger, Norbert (1992) "Zu den Verben auf Vedisch -anyá- und hethitisch -anniie-", Münchener Studien zur Sprachwissenschaft 53: 133-154.

Pokorny, Julius (1959) Indogermanisches etymologisches Wörterbuch, BernMünchen: Francke Verlag.

Rikov, Georgi T. (1992) "Sonants, Laryngeals and the Indo-European Nasal Infix Presents", Orpheus. Journal of Indo-European and Thracian Studies 2: 87-96.

Rikov, Georgi T. (1997) "Hittite (i)yanna-, Tocharian B yanem and the IndoEuropean Nasal Infix Presents of the Type CRenh ${ }_{x-}$, Orpheus. Journal of Indo-European and Thracian Studies 7: 9-36.

Rikov, Georgi T. (2018) Selected Papers on Indo-European Linguistics and Etymology, Sofia: Sofia University “St. Kliment Ohridski”. 
Rix, Helmut (1976) Historische Grammatik des Griechischen. Laut- und Formenlehre, Darmstadt: Wissenschaftliche Buchgesellschaft.

Rix, Helmut and Kümmel, Martin (2001) Lexikon der indogermanischen Verben. Die Wurzeln und ihre Primärstammbildungen, Wiesbaden: Dr Ludwig Reichert Verlag.

Scheungraber, Corinna (2014) Die Nasalpräsentien im Germanischen. Erbe und Innovation, Innsbruck: Institut für Sprachen und Literaturen der Universität Innsbruck.

Schwyzer, Eduard (1939) Griechische Grammatik, München: C. H. Beck'sche Verlagsbuchhandlung.

Strunk, Klaus (1967) Nasalpräsentien und Aoriste. Ein Beitrag zur Morphologie des Verbums im Indo-Iranischen und Griechischen, Heidelberg: Carl Winter Universitätsverlag.

Willi, Andreas (2018) Origins of the Greek Verb, Cambridge-New York: Cambridge University Press.

Witczak, Krzysztof Tomasz (2008) Pojęcie "Balkan-Indogermanisch" w perspektywie badań nad historia i genezq jezyka greckiego. Założenia i konsekwencje nowej metodologii, in: Marchewka, Anna (ed.) "Rem Acu Tangere". Studia Interdisciplinaria ad Linguam et Litteras Graecorum Antiquorum Pertinentia, Gdańsk: Wydawnictwo Uniwersytetu Gdańskiego, 17-28.

Witczak, Krzysztof Tomasz (2017) "Externalisierung der Flexion in indogermanische Ursprache”, Roczniki Humanistyczne 65(6): 93-111.

Witczak, Krzysztof Tomasz (2018) Two Greek Agent Nouns koipavos and ópavós in the Palaeo-Balkan and Indo-European Perspective, in: $2^{\text {nd }}$ International Conference on Greek Etymology: Greek and Balkan etymology, November $9^{\text {th }}-10^{\text {th }}, 2018$. Abstracts. Thessaloniki: Aristotle University of Thessaloniki, 28-29. 


\section{SAŽETAK}

Krzysztof Tomasz Witczak

\section{GRČKI DURATIVNI GLAGOLI S NAZALNIM INFIKSOM I SUFIKSOM}

Indoeuropski glagoli u prezentu koji sadrže infiks još uvijek nisu objašnjeni sa semantičkog gledišta. Autor ovoga rada zastupa tvrdnju da je infiks *-n(e)- izvorno izražavao svojstvo durativnosti. Zbog dijakronijske eksternalizacije fleksije ovaj se nazalni morfem kasnije razvio u sufiks koji se dodaje glagolskome korijenu. Brojni durativni glagoli s nazalnim markerom -an- mogu se pronaći u anatolijskim jezicima još u 2. tisućljeću prije Krista; usp. hetitski iy-ann-a/i- 'marširati, prijeći veliku razdaljinu', palajski iyannnai 'on maršira (marširanjem prelazi veliku razdaljinu)' nasuprot hetitiski $i$ - 'ići', luvijski $i-$, hijeroglifski luvijski $i-$, latinski eō, ìre, litavski eĩti, staroslavenski iti 'id.' (< PIE. *hlei- 'ići'). Durativni glagoli u pitanju, kao i imenice izvedene iz njih koje sadrže durativni sufiks *ano-, također se javljaju i u drugim indoeuropskim jezicima., usp. toharski B yanem 'oni hodaju, idu (dugo vremena)'. Brojni grčki prezentski oblici (npr. $\dot{\alpha} v \delta \dot{\alpha} v \omega, \theta \imath \gamma \gamma \dot{\alpha} v \omega, \lambda \alpha \mu \beta \dot{\alpha} v \omega, \lambda \alpha v \theta \dot{\alpha} v \omega, \lambda \imath \mu \pi \dot{\alpha} v \omega, \mu \alpha v \theta \dot{\alpha} v \omega$, $\pi v v \theta \alpha ́ v o \mu \alpha \imath$ itd.) sadrže isti nazalni morfem, ne samo kao infiks u glagolskome korijenu, već i u obliku sufiksa - $\alpha v$-. Ovo se objašnjava učinkom djakronijske eksternalizacije durativnoga (nazalnoga) morfema. Grčke glagolske oblike s nazalnim infiksom i nazalnim sufiksom treba smatrati prijelaznim oblicima ili hibridima. Noviji grčki oblici

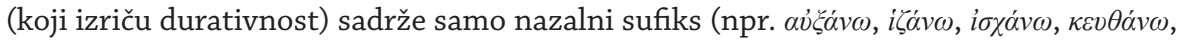
$\lambda \eta \theta \dot{\alpha} v \omega, o i \delta \alpha \dot{v} \omega \omega, \dot{\rho} o \varphi \alpha ́ v \omega)$.

Ključne riječi: starogrčki; durativni glagoli; eksternalizacija fleksije; indoeuropski jezici; nazalni infiks 